\title{
Ornamental potential of species from the ferruginous Campo rupestre of the Carajás National Forest, Brazilian Amazon
}

\author{
Renata Paschoal da Silva Sousa'*(i), Wendelo Silva Costa르, Paula e Silva Matos ${ }^{3}$, \\ Andréa Siqueira Carvalho ${ }^{4}\left(\right.$ ), Frederico Drumond Martins ${ }^{5}{ }^{\circ}$, Kátia Ribeiro Torres ${ }^{5}$ \\ 'Federal University of Paraná, Curitiba, Brazil \\ 2Federal University of Viçosa, Viçosa, Brazil \\ ${ }^{3}$ State University of Southwest Bahia, Vitória da Conquista, Brazil \\ ${ }^{4}$ Federal Rural University of Amazon, Parauapebas, Brazil \\ ${ }^{5}$ Chico Mendes Institute for Biodiversity Conservation, Parauapebas, Brazil \\ *Corresponding author, e-mail: renattarodrigues_@hotmail.com
}

\begin{abstract}
The flora of the ferruginous Campo rupestre that occur over the immense iron deposits of the Carajás National Forest is very unique, with several endemic and rare species. This vegetation is directly affected by mining activity, as a result of vegetation suppression and the profound disfigurement of habitats. The objective of this work was to identify the ornamental potential of the flora of the ferruginous Campo rupestre, as a strategy for ex situ conservation of ecosystem species. The species present in ten plots of $5 \times 5 \mathrm{~m}$ were surveyed in different areas of the ferruginous Campo rupestre on the $\mathrm{N} 1$ plateau and the ornamental potential of each species was evaluated following a characterization key, considering morphology and habitat of occurrence. Subsequently, the species were compared with those already present on the market, as ornamental, based on the literature and on sites specialized in the sale of ornamental plants in Brazil. A total of 33 species with ornamental potential were found, distributed in 32 genera and 19 families. Most species showed high functionality for ornamentation and similarity with nationally consolidated ornamentals. Catasetum planiceps, Cyrtopodium andersonii, Epidendrum nocturnum, Mandevilla scabra, Norantea guianensis and Sobralia liliastrum have a consolidated ornamental market. The data collected support ex situ conservation strategies of the flora of the ferruginous Campo rupestre, such as its valorization, local commercialization and income generation for small extractivists in the region.
\end{abstract}

Keywords: ferruginous grasslands, rupestrian grasslands, ex situ conservation, endemism

\section{Introduction}

Ferruginous Campo Rupestre (CRF) are unique ecosystems found on outcrops of iron ore, commonly known as iron cangas (Nunes et al., 2015). The plant community of these ecosystems is composed predominantly of herbaceous and shrub species, characterized by a high rate of endemism, rarity and high ornamental potential (Silva et al., 1996).

Brazilian CRFs are considered hotspots of plant biodiversity due to their association with iron ore deposits (Fernandes et al., 2014). Due to its relevance in the commodities market, the trend towards the exploitation of this mineral resource generates continued pressure on these ecosystems, which may result in the significant extinction of plant species, requiring the implementation of actions for their preservation in view of the conversion of these landscapes by the action of mining (Jacobi et al., 2011 ; Fernandes et al., 2014).
Native plants with ornamental potential have been the subject of research in various parts of the world, showing a tendency to look for new species for landscaping (Cavalcante et al., 2017). These can be more adapted to the conditions of the regions where they are naturally found, than exotic plants (Noya \& Cuquel, 2013). The commercial production of native plants legally regulated by Brazilian legislation, in accordance with the rules of the National System for the Management of Genetic Heritage - SISGEN, can be an important tool for ex situ conservation, through direct contribution to the dissemination, valorization and preservation of local biodiversity, but also for environmental education, with the spread of the regional landscape identity (Silva \& Perelló, 2010; Brasil, 2015; Stumpf et al., 2015).

Despite the great diversity of plants found in Brazil (Giulietti et al., 2005), most of the ornamental species used in the country are exotic (Gerhardt et al., 2011). 
The use of exotic species in landscaping contributes to the uniformity of landscapes, increase the invasive potential of these species and the low perception of the population in relation to the beauty of native vegetation (Heiden et al., 2006). In this sense, many landscape projects have presented a more ecological approach with a preservationist nature, through the prioritization of native species (Heiden et al., 2006; Oliveira-Júnior et al. 2013). However, exotic species are still predominant in landscape projects, mainly due to the scarcity of research and information on the use of native species, as well as the low supply of these species in commercial nurseries (Leal \& Biondi, 2006; Carrion \& Brack, 2012; Stumpf et al., 2015).

The use of CRF species in landscaping can be a complementary strategy for the ex situ conservation of this flora, in addition to contributing to the search for replacement of the use of exotic species in traditional landscaping. In view of this, the objective of this work was to characterize the ornamental potential of the flora of the ferruginous rock fields as a strategy for ex situ conservation of the species of this ecosystem.

\section{Material and Methods}

Study area

The study was carried out in a CRF area located on a canga plateau in the Serra Norte of the Carajás National Forest (region called N1 plateau), Federal Conservation Unit for Sustainable Use, located in the southeast of the State of Pará (Figure 1). According to the Köppen classification, the climate of the region is characterized as "Aw", presenting two well-defined seasons, rainy summer and dry winter. It has an average temperature between $23^{\circ} \mathrm{C}$ and $26^{\circ} \mathrm{C}$, with annual precipitation between 2000 and 2400 mm (Ab'Saber, 1986).

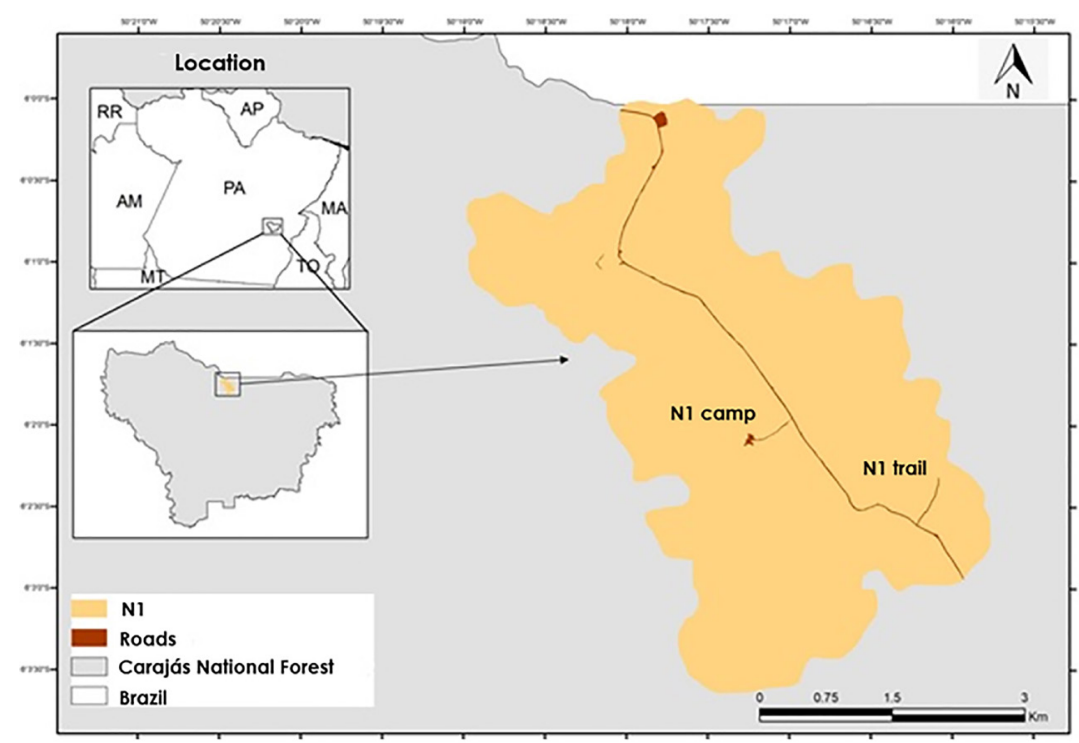

Figure 1. Location of the $\mathrm{Nl}$ canga plateau in the Serra Norte of the Carajás National Forest, southeastern Pará, Brazil.

Samples were made in the three main physiognomies, according to the classification by Silva (1991): natural grasslands (NG) - with a predominance of grass and other herbaceous species growing directly on the iron ore outcrops; xerophytic vegetation (XV) - greater diversity of herbaceous and shrub species associated with an accumulation of soil and organic matter; forest capão (FC) - more arboreal vegetation supported by a greater accumulation of organic soils.

\section{Data collection}

The sampling was concentrated in the region of the $\mathrm{N} 1$ plateau, one of the most pressured sites by mining in the Serra de Carajás. Ten plots of $5 \times 5$ meters (an area of $25 \mathrm{~m}^{2}$ per plot) were allocated, equidistant in 20 meters, at two sampling points: $\mathrm{N} 1$ trail (xerophytic vegetation and forest capões) and N1 camp (natural fields).

The species were identified in the field whenever possible. The unidentified individuals were photographed and exsiccates were made for later identification with the help of professionals of the Herbarium of the Vale Zoo and botanical Park (PZV). The collections were carried out in February 2016 (summer) and August 2016 (winter), months where the climatic season is more pronounced. The species were classified according to Angiosperm Phylogeny Group IV (APG IV, 2016) and the botanical nomenclature was carried out through consultations in the Tropicos (2018) and Flora do Brasil (2018) databases. 
To survey the potential ornamental use of the species, attributes of Chamas \& Matthes (2000) and Stumpf et al. (2009) were used, which consists of the observation of important characteristics for landscaping, such as texture and coloring of the main ornamental attributes of the species: leaves, flowers, branches and stems. Subsequently, the selected species were classified as Garden plants - indicated for massif formations, hedges, borders or isolated use; Pot plants - suitable for cultivation in different containers of different volumes; Multifunctional plants - suitable for gardens as well as for growing in pots (Stumpf et al., 2009). Data were also collected related to the habit of life (shrub, sub-shrub, herbaceous and climbing plants) and type of environment in which species occur (Silva, 1991). The species were classified according to luminosity (shade, sun or shade / sun).
The analogy with exotic and consolidated species in national landscaping was carried out using data from specific literature on ornamental plants (Lorenzi, 2013). The similarity between species was considered according to the methodology of Stumpf et al. (2015) with adaptations, in which morphological characteristics such as architecture, leaf shapes, flower and fruit, as well as the coloring of leaves and flowers were related.

After the identification of the species, a search was carried out on national sites for the commercialization of ornamental plants to see if any of the species found in the CRF already had a consolidated market.

\section{Results and Discussion}

Thirty-three plant species with ornamental potential were surveyed, which were distributed in 32 genera and 19 families (Table 1).

Table 1. Species with ornamental potential sampled in the ferruginous campo rupestre of the Carajás National Forest, Pará, Brazil.

\begin{tabular}{|c|c|c|}
\hline Family & Scientific name & Popular name \\
\hline Apocynaceae & Mandevilla scabra (Roem \& Schult.) K. Schum. & Alamanda \\
\hline \multirow{2}{*}{ Araceae } & Anthurium sinuatum Benth .ex Schott & - \\
\hline & Philodendron sp. & - \\
\hline \multirow{2}{*}{ Asteraceae } & Aspilia attenuata (Gardner) Baker & - \\
\hline & Lepidaploa cf. arenaria (Mart. ex DC.) H. Rob. & - \\
\hline Begoniaceae & Begonia saxicola A.DC. & - \\
\hline \multirow{2}{*}{ Bignoniaceae } & Anemopaegma longipetiolatum Sprague & Ipê da canga \\
\hline & Pleonotoma jasminifolia (H.B.K.) Miers & - \\
\hline \multirow{3}{*}{ Bromeliaceae } & Aechmea castelnavii Baker & - \\
\hline & Ananas ananassoides (Baker) L.B. Sm. & Abacaxi da canga \\
\hline & Dyckia duckei L. B. Sm. & - \\
\hline Cactaceae & Cereus hexagonus (L) Mill. & - \\
\hline \multirow{2}{*}{ Convolvulaceae } & Ipomoea cavalcantei D. F. Austin. & Flor de Carajás \\
\hline & Jacquemontia tamnifolia (L.) Griseb. & - \\
\hline \multirow[t]{2}{*}{ Eriocaulaceae } & Paepalanthus fasciculatus (Rottb.) Kunth & - \\
\hline & Bauhinia pulchella Benth. & Pata de vaca \\
\hline \multirow{3}{*}{ Fabaceae } & Dioclea virgata Mart. ExBenth & - \\
\hline & Mimosa skinneri var. carajarum Barneby & Mimosa \\
\hline & Periandra mediterranea (Vell.) Taub. & - \\
\hline \multirow{2}{*}{ Lythraceae } & Cuphea annulata Koehne & - \\
\hline & Cuphea carajasensis Lourteig & - \\
\hline Malphighiaceae & Byrsonima spicata (Cav.) Rich. ex Kunth & Murici da canga \\
\hline Marcgraviaceae & Norantea guianensis Aubl. & - \\
\hline \multirow{2}{*}{ Melastomataceae } & Pleroma carajasense K.Rocha, R.Goldenb. \& F.S.Mey & - \\
\hline & Tibouchina edmundoi Brade & - \\
\hline \multirow{4}{*}{ Orchidaceae } & Catasetum planiceps Lindl. & - \\
\hline & Cyrtopodium andersonii (Lamb. ex A.L. Andrews) R. Br. & - \\
\hline & Epidendrum nocturnum Jacq. & - \\
\hline & Sobralia liliastrum Lindl. & Sobralia \\
\hline Piperaceae & Peperomia macrostachya (Vahl) A.Dietr. & - \\
\hline Turneraceae & Turnera melochioides Cambess & - \\
\hline Velloziaceae & Vellozia glochidea Pohl. & Canela-de-ema \\
\hline Verbanaceae & Lippia origanoides Kunth & Erva cidreira \\
\hline
\end{tabular}

The Fabaceae and Orchidaceae families were the most representative, both with four species, followed by the Bromeliaceae family with three species.
The families Arecaceae, Asteraceae, Bignoniaceae, Convolvulaceae, Melastomataceae and Turneraceae presented two species and the other families only one. 
The ornamental potential of species of the Orchidaceae and Bromeliaceae families is already widespread in Brazil and directly responsible for the movement of the national market for ornamental plants (Anacleto \& Negrelle, 2009; Cardoso, 2014; Junqueira \& Peetz, 2014).

In a possible view of the management of these species in their natural environment, an important aspect to be observed is the number of individuals present in the ecosystem, fundamental for the elaboration of plans of ornamental potentiality of the species (Chamas \& Matthes, 2000). Floristic studies in the ferruginous campo rupestre of Carajás showed that the species Bauhinia pulchella,
Byrson imaspicata, Cuphea anullata, Dioclea virgata, Ipomoea cavalcantei, Lippia origanoides, Periandra mediterranea, Sobralia liliastrume, Vellozia glochidea are quite frequent and characteristics of the ecosystem (Silva et al., 1996; Nunes et al., 2015).

Indications ranged from garden use (66.5\%), multifunctional (30.5\%) and the epiphyte of forest capão areas. The only species of the survey indicated exclusively for use in pots was Peperomia macrostachya (3\%). Shrubs and sub-shrubs represented $39.4 \%$ (Figure 2), herbs $48.4 \%$ (Figure 3 ) and creepers $12.2 \%$ (Figure 4 ) of the raised species.
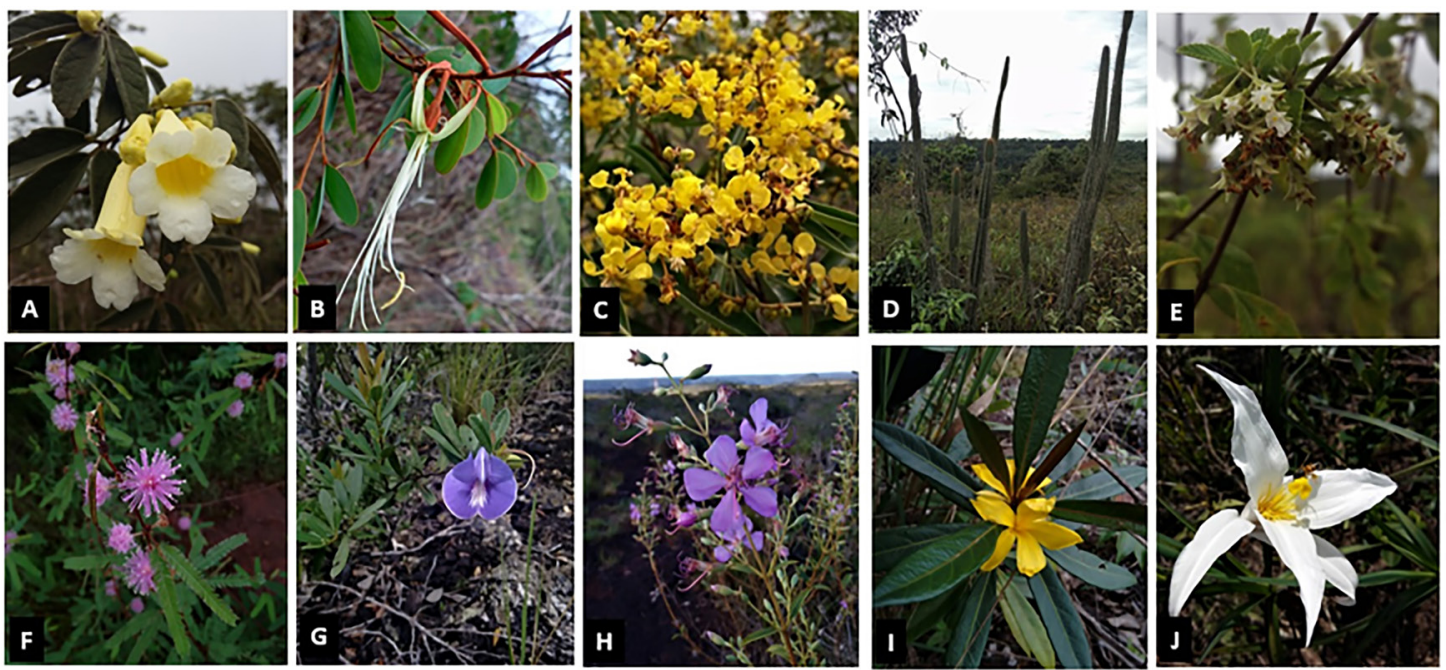

Figure 2. Shrub / sub-shrub species with ornamental potential from the ferruginous campo rupestre of the Carajás National Forest, State of Pará. A) Anemopaegma longipetiolatum; B) Bauhinia pulchella; C) Byrsonima spicata; D) Cereus hexagonus; E) Lippia origanoides; F) Mimosa skinneri var. carajarum; G) Periandra mediterrânea; H) Tibouchina edimundoi; I) Turnera melochioides; J) Vellozia glochidea. Photos: Wendelo Costa.
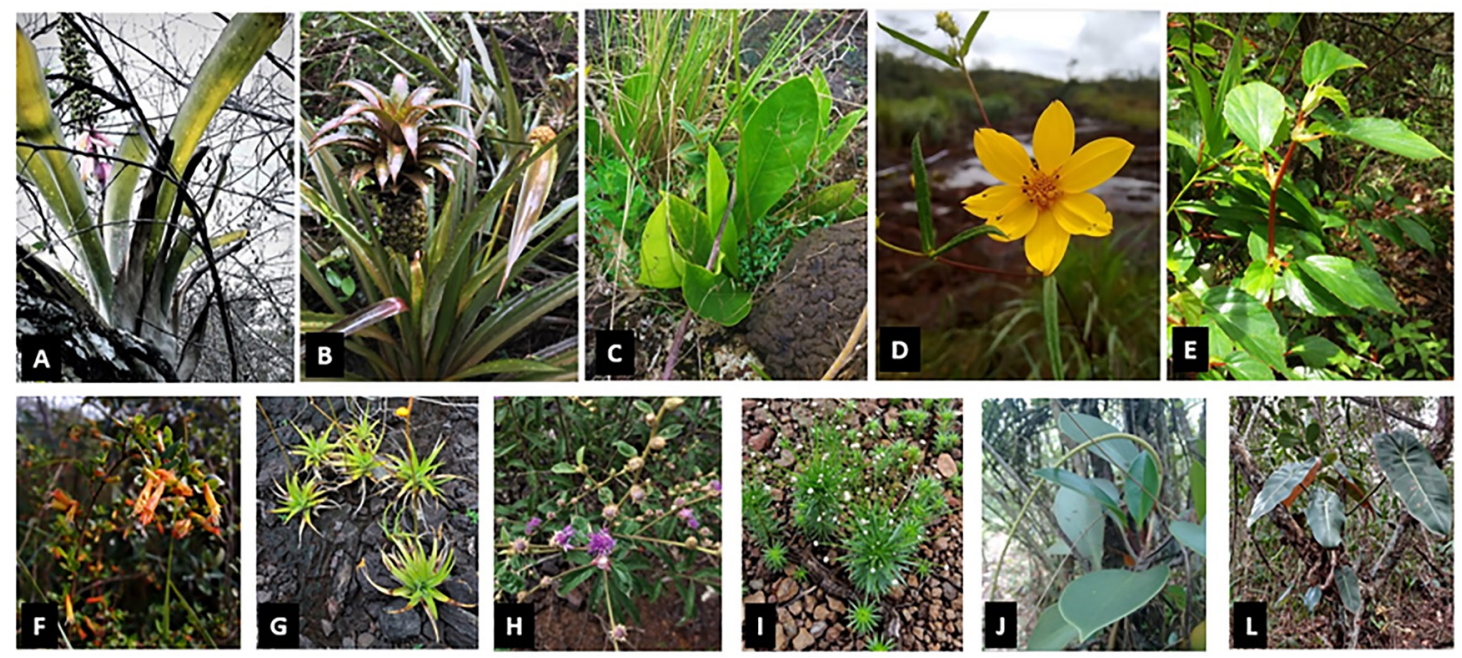

Figure 3. Herbaceous species with ornamental potential from the ferruginous campo rupestre of the Carajás National Forest, State of Pará. A) Aechmea castelnavii; B) Ananas ananassoides; C) Anthurium sinuatum; D) Aspilia attenuata; E) Begonia saxicola; F) Cuphea annulata; G) Dyckia duckei; H) Lepidaploa arenaria; I) Paepalanthus fasciculatus; J) Peperomia macrostachya; L) Philodendron sp. Photos: Wendelo Costa. 

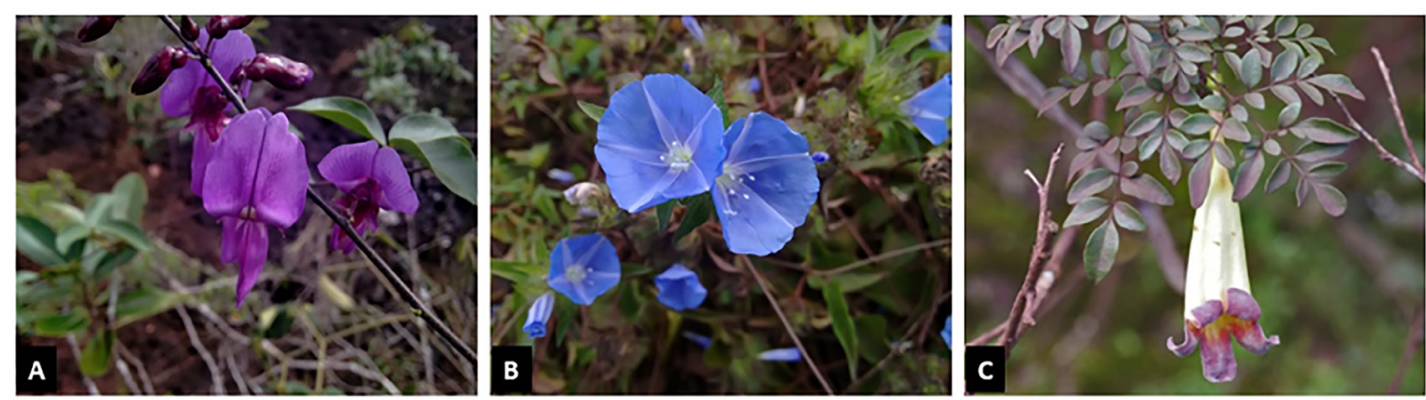

Figure 4. Climbing species with ornamental potential from the ferruginous campo rupestre of the Carajás National Forest, State of Pará. A) Dioclea virgata; B) Jacquemontia tamnifolia; C) Pleonotoma jasminifolia. Photos: A e B - Wendelo Costa; C- Pedro Viana.

All species, except for the vine Pleotoma jasminifoliae and the shurb L. origanoides, are classified as sun plants and indicated for use as garden plants. considered multifunctional because they can develop in different gradients of edaphic and luminous conditions (Table 2).

All species found in two types of environments are

Table 2. Ecological aspects (habit, luminosity and environment) and indications for the use of ornamental species in the ferruginous campo rupestre. XV - xerophytic vegetation; FC - Forest capão; NG - natural grasslands.

\begin{tabular}{|c|c|c|c|c|}
\hline Habit & species & Luminosity & Environment & Indication \\
\hline \multirow{7}{*}{ Shrub and } & Anemopaegma longipetiolatum & Sun & $\mathrm{XV}$ & Garden \\
\hline & Bauhinia pulchella & Sun & $X V$ & Garden \\
\hline & Byrsonima spicata & Sun & $\mathrm{XV}$ & Garden \\
\hline & Cereus hexagonus & Sun & $\mathrm{XV}$ & Garden \\
\hline & Lippia origanoides & Sun / shadow & $\mathrm{XV} / \mathrm{FC}$ & Multifunctional \\
\hline & Mandevilla scabra & Sun & $\mathrm{XV}$ & Garden \\
\hline & Mimosa skinneri var. carajarum & Sun & $X V$ & Garden \\
\hline \multirow{6}{*}{ Sub-shrub } & Norantea guianensis & Sun & $\mathrm{XV}$ & Garden \\
\hline & Periandra mediterrânea & Sun & $\mathrm{XV}$ & Garden \\
\hline & Pleroma carajasense & Sun & $\mathrm{XV}$ & Garden \\
\hline & Tibouchina edimundoi & Sun & $\mathrm{XV}$ & Garden \\
\hline & Turnera melochioides & Sun & $X V$ & Garden \\
\hline & Vellozia glochidea & Sun & $\mathrm{XV}$ & Garden \\
\hline \multirow{16}{*}{ Herbaceous } & Aechmea castelnavii & Sun / shadow & $\mathrm{XV} / \mathrm{FC}$ & Multifunctional \\
\hline & Ananas ananassoides & Sun & $\mathrm{XV}$ & Garden \\
\hline & Anthurium sinuatum & Sun / shadow & $\mathrm{XV}$ & Multifunctional \\
\hline & Aspilia attenuata & Sun & NG & Garden \\
\hline & Begonia saxicola & shadow & $\mathrm{FC}$ & Multifunctional \\
\hline & Catasetum planiceps & Sun / shadow & $\mathrm{XV} / \mathrm{FC}$ & Multifunctional \\
\hline & Cuphea annulata & Sun & $\mathrm{XV}$ & Multifunctional \\
\hline & Cuphea carajasensis & Sun & $\mathrm{XV}$ & Multifunctional \\
\hline & Cyrtopodium andersonii & Sun / shadow & $\mathrm{XV} / \mathrm{FC}$ & Multifunctional \\
\hline & Dyckia Duckei & Sun & $\mathrm{XV}$ & Multifunctional \\
\hline & Epidendrum nocturnum & Sun / shadow & $\mathrm{XV} / \mathrm{FC}$ & Multifunctional \\
\hline & Lepidaploa arenaria & Sun & $\mathrm{XV}$ & Garden \\
\hline & Paepalanthus fasciculatus & Sun & NG & Garden \\
\hline & Peperomia macrostachya & shadow & $\mathrm{XV}$ & Vase \\
\hline & Philodendron sp. & Sun / shadow & $X V$ & Garden \\
\hline & Sobralia liliastrum & Sun & $\mathrm{XV} / \mathrm{FC} / \mathrm{NG}$ & Multifunctional \\
\hline \multirow{4}{*}{ Climbing } & Dioclea virgata & Sun & $\mathrm{XV}$ & Garden \\
\hline & Ipomoea cavalcantei & Sun & $\mathrm{XV}$ & Garden \\
\hline & Jacquemontia tamnifolia & Sun & $\mathrm{XV}$ & Garden \\
\hline & Pleonotoma jasminifolia & shadow & FC & Garden \\
\hline
\end{tabular}

The species S. liliastrum was found in all environments of the ecosystem. This species is a terrestrial orchid that can reach 1.2 meters in height, has a Neotropical distribution and has great environmental plasticity (Romero-González, 2003; Pessoa \& Alves, 2011).
The other species of the Orchidaceae family were found with terrestrial habit both in rocky vegetation and in forest capão areas. The species Catasetum planiceps is considered a terrestrial species, however studies show that Cyrtopodium andersonii and, mainly Epidendrum 
nocturnum, were found as preferentially epiphytic orchids (Silva et al., 1999; Mania \& Monteiro, 2010, PetiniBenelli \& Castro, 2015). This variation of environments can be an important characteristic for the elaboration of conservation and domestication strategies for these species outside their natural environment. Chamas \& Matthes (2000) affirmed that ecological characteristics such as the environment and luminosity are fundamental for a species to be indicated for the landscape market. potential showed similarities with ornamentals used nationally (Table 3). About $71 \%$ of the species are of native origin (17) and $29 \%$ exotic (7). Regarding the parameters of similarity analyzed, Ananas annanassoides, Aspilia attenuata, Jacquemontia tamnifolia, Pleroma carajasense and Tibouchina edmundoi presented a higher level of proximity with consolidated ornamentals, similar in five parameters (architecture, leaf and flower shape and coloration of leaves and flowers).

Most of the species surveyed with CRF ornamental

Table 3. Comparison of native ornamental species from the Carajás National Forest with species consolidated nationally as ornamental. NAT - Native; EXO - Exotics. ARQ - Architecture; FOL - Leaves; FLO - Flowers; FRU - Fruits; CFO - Leaf coloring; CFL Coloring of flowers.

\begin{tabular}{|c|c|c|c|}
\hline Scientific name & Consolidated Ornamental Species & Origin & Similar Features \\
\hline A. ananassoides & Ananas bracteatus (Lindl.) Schult. \& Schult. F. & NAT & ARQ; FOL; FLO; CFO; FRU. \\
\hline A. attenuata & Bidens sulphurea (Cav.) Sch.Bip. & EXO & ARQ; FOL; FLO; CFO; CFL. \\
\hline A. castelnavii & Aechmea chantinii (Carrière) Baker & NAT & $\mathrm{ARQ} ; \mathrm{FOL} ; \mathrm{FLO}$ \\
\hline A. longipetiolatum & - & - & - \\
\hline A. sinuatum & Anthurium crystallinum Linden \& André & EXO & ARQ; FOL; FLO; CFO. \\
\hline B. saxicola & Begonia reniformis Dryand. & NAT & ARQ; FLO; CFL. \\
\hline B. spicata & Peixotoa reticulata Griseb. & NAT & $A R Q ; F L O ; C F O ; C F L$. \\
\hline B.pulchella & Bauhinia tomentosa L. & EXO & ARQ; FOL; CFO. \\
\hline C. andersonii & Cyrtopodium andersonii & & $(4 ; 6$ e 7$)$ \\
\hline C. annulata & Cuphea gracilis Kunth. & NAT & ARQ; FOL; FLO; CFL. \\
\hline C. carajasensis & Cuphea melvilla Lindl. & NAT & ARQ; FLO; CFL. \\
\hline C. hexagonus & Pilosocereus gounellei (F.A.C Weber) Byles \& G.D Rowley & NAT & ARQ. \\
\hline C. planiceps & Catasetum planiceps & & $(1$ e 7$)$ \\
\hline D. duckei & Dyckia brevifolia Baker & NAT & ARQ; FLO; CFO; CFL. \\
\hline D. virgata & Dioclea violacea Mart. Ex Benth. & NAT & ARQ; CFO; CFL. \\
\hline E. nocturnum & Epidendrum nocturnum & & $(5,6$ e 7$)$ \\
\hline I. cavalcantei & Ipomoea hederifolia L. & NAT & ARQ; FLO; CFO; CFL; \\
\hline J. tamnifolia & Evolvulus brevifolius (Meisn.) Ooststr. & NAT & ARQ; FOL; FLO; CFO; CFL. \\
\hline L. arenaria & Liatris spicata (L.) Willd. & EXO & $\mathrm{ARQ}$ \\
\hline L. origanoides & Duranta erecta $\mathrm{L}$. & EXO & ARQ; FLO; CFO; CFL; \\
\hline M. scabra & Mandevila scabra & & (8) \\
\hline M. skinneri var. carajarum & Calliandra brevipes Benth. & NAT & FOL; FLO; CFO; CFL. \\
\hline N. guianensis & Norantea guianensis & & $(2)$ \\
\hline P. carajasense & Tibouchina heteromalla (D. Don) Cogn. & NAT & ARQ; FOL; FLO; CFO; CFL. \\
\hline P. fasciculatus & - & - & - \\
\hline Phylodendrum sp. & Philodendron gloriosum André & EXO & ARQ; FOL; CFO. \\
\hline P. jasminifolia & - & - & - \\
\hline P. macrostachya & Peperomia magnoliifolia (Jaca.) A. Dietr. & NAT & ARQ; FOL; CFO. \\
\hline P. mediterrânea & - & - & - \\
\hline S. liliastrum & Sobralia liliastrum & & $(1$ e 3) \\
\hline T. edmundoi & Tibouchina mutabilis (Vell.) Cogn. & NAT & ARQ; FOL; FLO; CFO; CFL. \\
\hline T. lochioides & Turnera sulubata Sm. & NAT & ARQ; COL; FLO; CFO. \\
\hline V. glochidea & Dracena marginata Lam. & EXO & $A R Q ; F O L$. \\
\hline
\end{tabular}

(-) Species that have no resemblance to consolidated ornamental species.

(1) https://www.bvorchids.com.br

(2) http://ciprest.blogspot.com

(3) https://cooperorchids.com

(4) https://orquidariodaspedras.com.br

(5) https://www.orquidariorecantodasflores.com.br

(6) https://www.orquidariosantabarbara.com

(7) http://www.seidel.com.br

(8) https://www.terraviva.agr.br 
The species Anthurium sinuatum, B. spicata, C. anulata, Dyckia duckey, I. cavalcantei, L. origanoides, Mimosa skinneri var. carajarum and Turnera melochioides showed similarity in the four parameters evaluated. Aechmea castelnavii, Begonia saxicola, B. puchela, Cuphea carajasensis, D. virgata, P. macrostachya and Phylodendrum sp. showed similarity in three parameters. The species Vellozia glochidea showed similarity in two parameters (architecture and leaves). Cereus hexagonus and L. arenaria demonstrated low similarity with the consolidated ornamental species, in only a comparative aspect (architecture). The species Anemopaegma longipetiolatum, P. jasminifolia, Paepalanthus fasciculatus and $P$. mediterranea had no resemblance to any consolidated ornamental. While the orchids $C$. planiceps, C. andersonii, E. nocturnum and S. liliastrum and the Mandevila scabra and Norantea guianensis shrubs showed ornamental potential known in Brazilian landscaping (Figure 5).
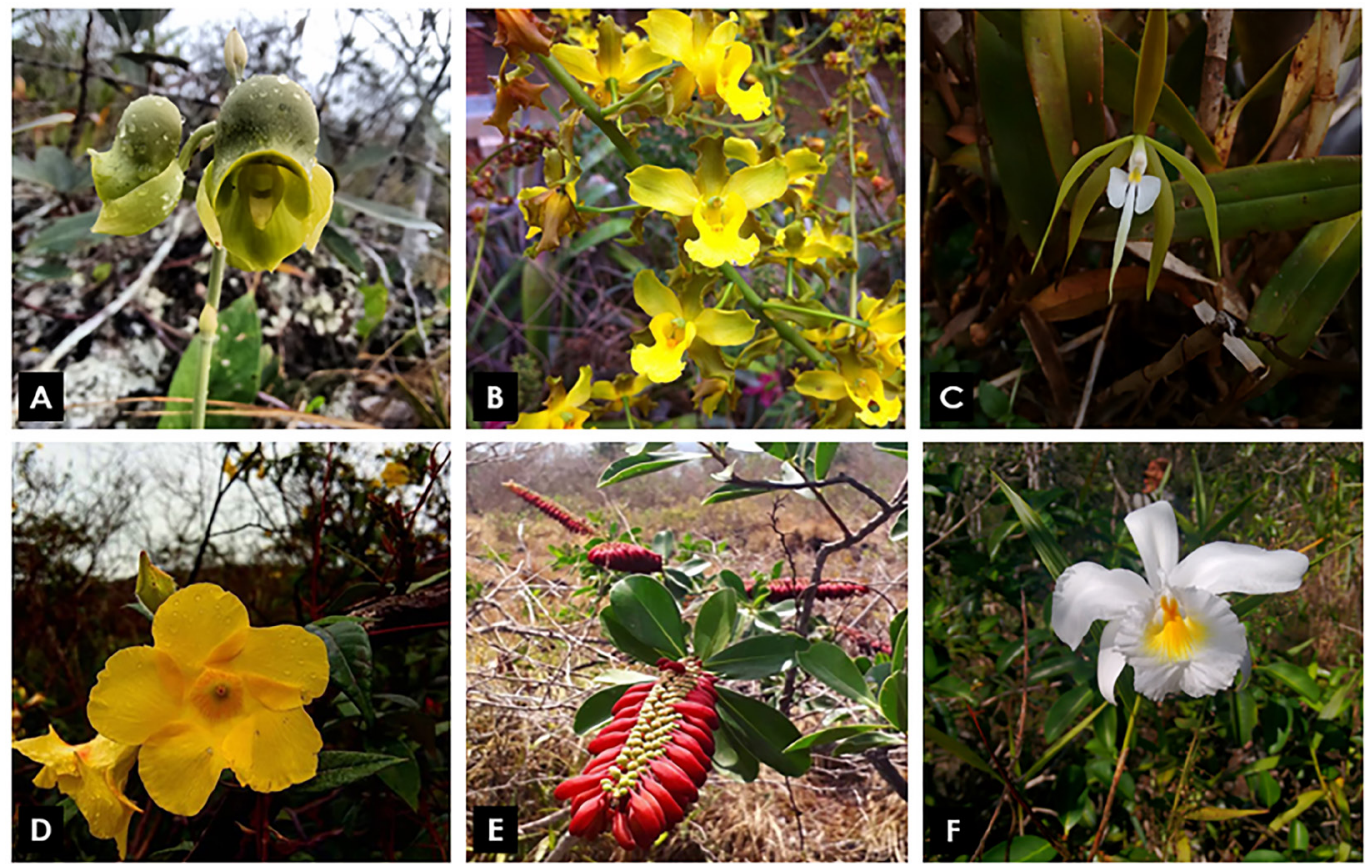

Figure 5. Species native to the ferruginous campo rupestre of the Carajás National Forest, State of Pará, which have a consolidated ornamental market on ornamental plant sites in Brazil. A) Catasetum planiceps; B) Cyrtopodium andersonii; C) Epidendrum nocturnum; D) Mandevilla scabra; E) Norantea guianensis; e F) Sobralia liliastrum. Photos: Wendelo Costa.

Comparing native CRF species with ornamental species consolidated in the national market is very important in the context of the region. The regional economy revolves mainly around mining (Palheta ef al., 2017) and the new areas for opening mines within the Carajás National Forest suppress the CRF. The species prospected in this study occur in these areas of suppression and have no viable destination ecologically or economically.

The species C. carajasensis, I. cavalcantei and P. carajasense are endemic species of Serra dos Carajás (Mota et al., 2018) (Figure 6). The inclusion of these species in crops would be essential to ensure their conservation, especially in the case of I. cavalcantei, a species symbol of the ferruginous rock field and restricted to a very small portion of the ecosystem often impacted by mining (Lanes et al., 2018). The use of endemic species in landscape projects is an alternative to environmental degradation caused by vegetation suppression in natural ecosystems (Cavalcante et al., 2017; Stumpf et al., 2009).

An alternative for ex situ conservation of native species would be the extractivism practiced by the Cooperative of Extractivists of Carajás (COEX) that collect seeds of forest species and extract leaves of the species Jaborandi (Pilocarpus microphyllus Stapfex Wardlew) at Carajás National Forest. The investment in native ornamental species could complement the cooperative's activity in the Conservation Unit, through income generation with sustainable management and diversification of the local economy. Oliveira Júnior et al. (2013) demonstrated that an economic diversification of agroecological systems with the inclusion of native ornamental species generates in a temporal perspective of management of the areas, income for family maintenance. 

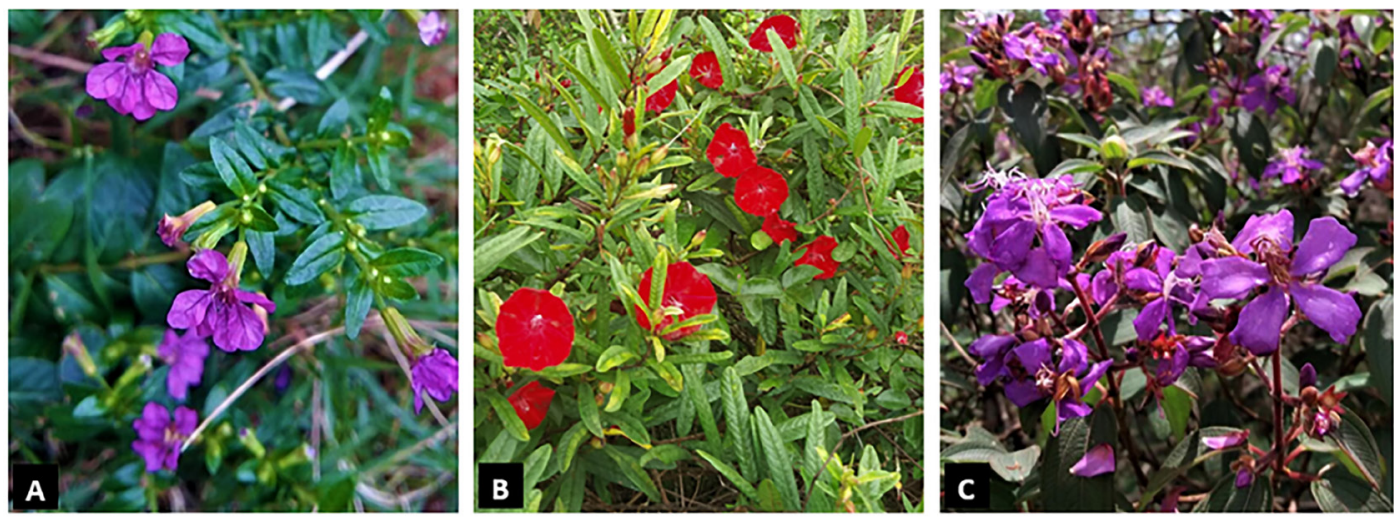

Figure 6. Species endemic to the ferruginous campo rupestre of the Carajás National Forest, State of Pará with ornamental potential. A) Cuphea carajasensis; B) Ipomoea cavalcantei; C) Pleroma carajasense. Photos: Wendelo Costa.

Ornamental species can also be used in the process of environmental valuation of the CRF. In a study conducted by Ramalho \& Pimenta (2010), it was demonstrated that it is possible to use environmental valuation methodologies to reach a value applicable to the impact caused to the population of native flora species, as occurred with the orchid species Cattleya granulosa Lindl. in protected areas.

The National System of Conservation Units (SNUC) provides compensation for areas of vegetation suppression (MMA, 2011), but in FLONA de Carajás, the methodology for compensation calculations prioritizes, almost absolutely, attributes of a timber nature, mainly found in areas of Ombrophilous Forest, which causes negligible values for suppression in areas of CRF, where the predominant vegetal layer is herbaceous. Thus, the recognition of the ornamental potential of species already commercialized nationally, such as $C$. andersonii, C. planiceps, E. nocturnum, N. guianensis, M. scabra and $S$. liliastrum can contribute to a better dimensioning of the damage and consequent elaboration of better calculations in the face of the degradation of the vegetation of CRF areas, increasing the amounts paid in indemnification processes of new areas suppressed for mining.

The ornamental potential of the species surveyed at work is essential in the conservation process of these species outside their natural environment. Most of the species surveyed demonstrated their aptitude for ornamental use through the similarity with plants used nationally, suggesting the need for future studies on their domestication, with the purpose of economic uses through commercialization and consequent ex situ conservation. In addition, it is worth emphasizing the importance of considering the recognition of this ornamental potential in the indemnification processes of plant suppression in areas of ferruginous Campo Rupestre.

\section{Conclusions}

The species prospected on the $\mathrm{N} 1$ plateau show that the flora of the ferruginous Campo Rupestre of the Carajás National Forest has potential for different applications in landscaping.

The ornamental potential found in the 33 species analyzed brings an alternative to vegetative suppression of the ferruginous Campo Rupestre, through the use of these species in landscaping and consequent ex situ conservation of the unique flora of the ecosystem.

\section{References}

Ab'Saber, A.N. 1986. Geomorfologia da região. In: Almeida-Júnior (Org). Carajás: desafio político, ecologia e desenvolvimento. CNPq, São Paulo, Brazil. p. 88-124.

Anacleto, A., Negrelle, R.R.B. 2009. Extrativismo de rametes e propagação vegetativa de Aechmea nudicaulis (L.) GRISEB. (Bromeliaceae). Feddes Repertorium 126: 16-21.

APG IV: The Angiosperm Phylogeny Group. 2016. An update of the Angiosperm Phylogeny Group classification for the orders and families of flowering plants: APG IV. Botanical Journal of the Linnean Society 181: 1-20.

BRASIL. Patrimônio Genético e Conhecimentos Tradicionais Associados, 2015. https://www.mma.gov.br/ patrimonio-genetico.html<Access on 10 Mar. 2018>

Cardoso, J.C. 2014. Levantamento de espécies da família Orchidaceae em Botucatu: potencial ornamental e cultivo. Horticultura Brasileira 32: 7-13.

Carrion, A.A., Brack, P. 2012. Eudicotiledôneas ornamentais dos campos do bioma Pampa no Rio Grande do Sul. Revista Brasileira de Horticultura Ornamental 18: 23-37.

Cavalcante, M.Z.B., Dultra, D.F.S., Silva, H.L.C., Cotting, J.C., Silva, S.D.P., Siqueira-Filho, J.A. 2017. Potencial ornamental de espécies do Bioma Caatinga. Comunicata Scientiae 8: 43-58.

Chamas, C.C., Matthes, L.A. 2000. Método para levantamento de espécies nativas com potencial ornamental. Revista Brasileira de Horticultura Ornamental 6: 53-63. 
Fernandes, G.W., Barbosa, N.P.U., Negreiros, D., Paglia, A.P. 2014. Challenges for the conservation of vanishing megadiverse rupestrian grasslands. Natureza e Conservação 12: 162-165.

Flora do Brasil. Flora do Brasil 2020 em construção. Jardim Botânico do Rio de Janeiro. 2018. http://floradobrasil.jbrj. gov.br/<Access on 10 Mar. 2018>

Gerhardt, M.C., Muller, N.G., Wolski, S.R.S. 2011. Diagnóstico da arborização da área central da cidade de Santo Cristo-RS. Revista da Sociedade Brasileira de Arborização urbana 6: 69-84.

Giulietti, A.M., Harley, R.M., Wanderley, M.G.L., Berg, C.V.D. 2005. Biodiversidade e conservação de plantas no Brasil. Megadiversidade 1: 52-61.

Heiden, G., Barbieri, R., Stumpf, E.R.T. 2006. Considerações sobre o uso de plantas ornamentais nativas. Revista Brasileira de Horticultura Ornamental 12: 2-7.

Jacobi, C.M., Carmo, F.F., Campos, I.C. 2011 . Soaring extinction threats to endemic plants in Brazilian metal-rich regions. Ambio 40: 540-543.

Junqueira, A.H., Peetz, M.S. 2014. O setor produtivo de flores e plantas ornamentais do Brasil, no período de 2008 a 2013: atualizações, balanços e perspectivas. Revista Brasileira de Horticultura Ornamental 20: 115-120.

Lanes, E.C., Pope, N.S., Alves, R., Carvalho Filho, N.M., Giannini, T.C., Giullieti, A.M., Imperatriz-Fonseca, V.L. Monteiro, W., Oliveira, G., Silva, A.R., Siqueira, J.O., SouzaFilho, P.W., Vasconcelos, S., Jaffe, R. 2018. Landscape Genomic Conservation Assessment of a Narrow-Endemic and a Widespread Morning Glory From Amazonian Savannas. Frontiers in Plant Science 9: a. 532.

Leal, L., Biondi, D. 2006. Potencial Ornamental de espécies nativas. Revista Científica Eletrônica de Engenharia Florestal 4: 1-16.

Lorenzi, H. 2013. Plantas para jardim no Brasil: herbaceas, arbustivas e trepadeiras. 1.ed. Instituto Plantarum, Nova Odessa, Brazil. 1120 p.

Mania, L.M., Monteiro, R. 2010. Florística e ecologia de epífetas vasculares em um fragmento de floresta de restinga, Ubatuba, SP, Brasil. Rodriguésia 61: 705-713.

Ministério do Meio Ambiente. MMA. 2011. Sistema Nacional de Unidades de Conservação da Natureza. Brasilia-DF. https://www.mma.gov.br/estruturas/240/_ publicacao/240_publicacao0607201 1055602.pdf <Access on 10 Mar. 2018>

Mota, N.F.O., Watanabe, M.T.C., Zappi, D.C., Hiura, A.L., Pallos, J., Viveiros, R.S., Giulietti, A.M., Viana, P.L. 2018. Cangas da Amazônia: a vegetação única de Carajás evidenciada pela lista de fanerógamas. Rodriguésia 69: 1435-1488.

Noya, M.G., Cuquel, F.L. 2013. Potencial de uso de condições de cultivo de Stenachaenium megapotamicum uma planta ornamental. Revista Brasileira de Horticultura Ornamental 19: 149-154.
Nunes, J.A., Schaefer, C.E.G.R., Júnior, W.G.F., Neri, A.V., Correa, G.R., Enright, N.J. 2015. Soil-vegetation relationship on a banded ironstone 'island', Carajás plateau, Brasilian Eastern Amazonia. Anais da Academia Brasileira de Ciências 87: 2097-2110.

Oliveira-Júnior, C.J.F., Gonçalvez, F.S., Couto, F., Matajs, L. 2013. Potencial das espécies nativas na produção de plantas ornamentais e paisagismo agroecológico. Revista Brasileira de Agroecologia 8: 190-200.

Palheta, J.M., Silva, C.N., Oliveira-Neto, A., Nascimento, F.R. 2017. Conflito pelo uso do território na Amazônia Mineral. Mercator 16: 1-18.

Pessoa, E., Alves, M. 2011 . Orchidaceae Juss. Na Serra de Itabaiana, Sergipe, Brazil. Revista Caatinga 24: 102-1 14.

Petini-benelli, A., Castro, A.S.F. 2015. New record in Catasetum (Orchidaceae) for the State of Ceará, Brazil. Feddes Repertorium 126: 16-21.

Ramalho, A.M.Z., Pimenta, H.C.D. 2010. Valoração econômica aplicada à extração ilegal da orquídea Cattleya granulosa no Parque Natural Dom Nivaldo Monte de Natal/RN. Engenharia Ambiental 7: 181-194.

Romero-gonzalez, G.A. 2003. The Sobralia liliastrum (Orchidaceae: Sobraliinae) complex in the Venezuela Guyana. Harvard Papers in botany 8: 115-129.

Silva, J.G., Perelló, L.F.C. 2010. Conservação de espécies ameaçadas do Rio Grande do Sul através de seu uso no paisagismo. Revista da Sociedade Brasileira de Arborização Urbana 5: 1-21.

Silva, M.F.F. 1991. Análise florística da vegetação que cresce sobre canga hematítica em Carajás, Pará (Brasil). Boletim do Museu Paraense Emílio Goeldi, Série botânica 7: 79-108.

Silva, M.F.F., Silva, J.B.F., Feiler, J.M. 1999. Orchidaceas do Estado do Maranhão, Brasil. Acta Amazônica 29: 381-393.

Silva, M.F.F., Secco, R.S., Lobo, M.G. 1996. Aspectos ecológicos da vegetação rupestre da Serra dos Carajás, Estado do Pará, Brasil. Acta amazônica 26: 17-44.

Stumpf, E.R.T., Silva, P.S., Romagnoli, I.D., Fischer, S.Z., Mariot, M.P. 2015. Espécies nativas que podem substituir exóticas no paisagismo. Horticultura Ornamental 21: 165172.

Stumpf, E.R.T., Romano, C.M., Barbieri, R.L., Heiden, G., Fischer, S.Z., Corrêa, L.B. 2009. Características ornamentais de plantas do Bioma Pampa. Revista Brasileira de Horticultura Ornamental 15: 49-62.

Tropicos.org. Missouri Botanical Garden. 2018. http:// www.tropicos.org/ <Access on 10 Mar. 2018>

Conflict of Interest Statement: The authors declare that the research was conducted in the absence of any commercial or financial relationships that could be construed as a potential conflict of interest.

All the contents of this journal, except where otherwise noted, is licensed under a Creative Commons Attribution License attribuition-type BY. 